\title{
The Effect of E-learning Scaffolding (Direct vs. Indirect) in a flipped classroom on developing audio programs design and production skills and learning involvement among Specific Education College students
}

\begin{abstract}
Ahlam Eldesoky
Faculty of Education, Assiut University

E-mail: ahlam.ibrahim@edu.aun.edu.eg

\section{ABSTRACT.}

This study aimed at measuring the effect of E-leaning scaffolding (Direct Vs. Indirect) within a flipped classroom on developing audio-digital software production and design skills as well as learning involvement among students of the College of Specific Education in Assiut University, The pre-posttest one-group research design was adopted. The participants included 60 first year students in the Technology of Education Department in Assiut University. They were divided into two experimental groups; 1 st experimental group $(\mathrm{N}=30)$ studying through E-learning direct scaffolding technique and the 2nd experimental group $(\mathrm{N}=30)$ studying through E-learning indirect scaffolding technique. The study included four variables: achievement, skill performance, quality of design and production of audio-digital software and learning involvement. Results revealed that there were statistically significant differences on level $\leq 0.05$ among the post applications mean scores of the $1^{\text {st }}$ experimental group students and those of the $2^{\text {nd }}$ experimental one favoring those of the $1^{\text {st }}$ experimental group.

Keywords. Flipped Classroom; E-learning Direct; Indirect Scaffolding; Achievement; Skill Performance; Learning Involvement
\end{abstract}

Citation: Eldesoky, A. The Effect of E-learning Scaffolding (Direct vs. Indirect) in a flipped classroom on developing audio programs design and production skills and learning involvement among Specific Education College students, SVU-Journal of abstract 2021, 3 (1): pp4 (retrieved from the SVU- International Journal Of Educational Sciences,2021, No $6)$.

Copyright: Publisher: South Valley University. This is an open access article distributed under the terms of the creative common attribution license, which permits unrestricted use, distribution and reproduction in any medium provided the original author and source are created. 